Marta BUKowiEcka

Polska Akademia Nauk*

iD https://orcid.org/0000-0002-0405-7747

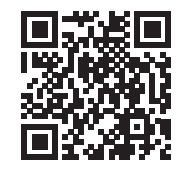

\title{
Kontrasty, deformacje, demontaże. Literackie przetwarzanie form nieliterackich w literaturze polskiej po 1956 roku
}

Contrasting, Deforming, Dismantling. Literary Processing of Non-Artistic Language in Polish Literature after 1956

\begin{abstract}
The text concerns the expansion of non-artistic forms of language in Polish literature after the "Polish thaw". They are separated from real context, processed in an experimental, radical and original way and (re)used in the literary work as linguistic, ready-made objects or as a part of artistic recycling. I point out three strategies of language processing: contrasting, deforming and dismantling, which are present in works by three post avant-garde writers: Leopold Buczkowski, Tadeusz Różewicz and Miron Białoszewski. Striving for innovation and experiment, thinking of language with growing suspicion, focusing on its tendency to petrification allows their work to be seen as the continuation of modernist tendencies.
\end{abstract}


* Pracownia Poetyki Historycznej Instytutu Badań Literackich PAN ul. Nowy Świat 72, p. 128, 00-330 Warszawa

e-mail:marta.bukowiecka@ibl.waw.pl 
Inwazja form nieliterackich, użytkowych, potocznych w polskiej literaturze współczesnej ma dość długą historię, nasila się od czasów odwilży 1956 roku. Dotyczy twórczości autorów różnych pokoleń, grup, środowisk (m.in. twórców pokolenia 56 i pokolenia 68, a ściślej Nowej Fali, poetów lingwistycznych i neolingwistycznych, akolitów Henryka Berezy z kręgu ogłoszonej przez niego „rewolucji artystycznej”, wielu autorów debiutujących po 1989 roku, ze środowiska „Brulionu” i młodszych), a także twórców niezrzeszonych i osobnych (np. Leopolda Buczkowskiego, Tadeusza Różewicza, Mirona Białoszewskiego, Mariana Pankowskiego, Edwarda Redlińskiego, Janusza Głowackiego, Tadeusza Siejaka, Doroty Masłowskiej i wielu innych). W kontekście problematyki awangardowości i innowacyjności w literaturze interesujący wydaje się problem oryginalnego, eksperymentalnego przetwarzania tych form.

Formy nieliterackie można rozumieć rozmaicie, jako gotowe, całościowo ujmowane teksty użytkowe i ich pojedyncze fragmenty czy właściwości: urywki z reklam i gazet, schematy konwersacyjne, klisze językowe, elementy stylów funkcjonalnych, cytaty z zasłyszanych wypowiedzi ustnych czy skonwencjonalizowane zachowania językowe. Wszystkie tego rodzaju wypowiedzi odbiegają od normy neutralnej, wzorcowej polszczyzny literackiej. Niegdyś, w latach 50. i 60. pojawiały się w literaturze raczej na prawach obcej mowy, werbalnego rekwizytu postaci z pozainteligenckich środowisk. W latach 70 . upowszechniły się i stały tworzywem śmiałych eksperymentów (Karpowicz 2012). A w latach 90., czy już w XXI wieku, zatraciły swoją ekscentryczną wartość i znaczenie literackiego ekscesu, stały się częścią języka literackiego, która nikogo już raczej nie dziwi. Można by powiedzieć za Ryszardem Nyczem, że literatura drugiej połowy XX wieku wyparła modernistyczną ideę ekskluzywnej odrębności języka literackiego względem języka ogólnego w imię reguły inkluzywnego włączania różnych odmian mowy do literatury (Nycz 2012: 204). „Cudze słowa” (Bachtin 1970) od 60 lat coraz silniej wrastają w język literatury, stając się jego niezbywalną częścią.

Eksperymentalne wykorzystywanie nieartystycznych form wypowiedzi ma cel pozornie sprzeczny. Wiąże wypowiedź artystyczną z realnymi praktykami mowy, odzwierciedla je, odtwarza, rekonstruuje, czyni z nich istotną kwestię, a więc w pewnym sensie osadza literaturę w rzeczywistości. Mocne przetworzenie wypowiedzi, zwłaszcza radykalna eksperymentalna transformacja, odcina jednak wypowiedź od sytuacji mówienia. Eksperyment niejako uprzedmiotawia ją, nadaje jej charakter i funkcję artystycznego tworzywa. Ale choć odrywa mowę od jej użycia, to nie czyni tekstu autotelicznym. Eksperymentalne przetworzenie 
zmierza często do obnażenia i problematyzowania mechanizmów potocznych praktyk językowych. Jest zatem formą krytycznego odniesienia się do języka.

Zasadniczo techniki ponownego wykorzystywania form nieliterackich można podzielić na nieinwazyjne i inwazyjne. Nieinwazyjne opierają się na mechanizmie przeniesienia wypowiedzi w obręb dzieła literackiego na zasadzie tekstowego ready-made. „Surowe kawałki rzeczywistości” (Redliński 1982) — by użyć sformułowania Edwarda Redlińskiego, który złożył swój utwór, Nikiformy, z gotowych tekstów użytkowych — zyskują rangę materii artystycznej na mocy decyzji autora, który nadaje słowu odmienną niż pierwotna funkcję w nowym kontekście literackim. Językowe uchybienia przez widoczny zamysł ich opisu stają się obiektem estetycznej literackiej ekspozycji, tematem żartu czy elementem krytycznej analizy języka (Bukowiecka 2015).

Techniki wykorzystywania nieartystycznych odmian i właściwości języka w omawianej tu literaturze nie sprowadzają się rzecz jasna tylko do cytowania. Polegają na radykalnej ingerencji w znaczenie i formę wypowiedzi, wiążą się z jej „inwazyjnym” zniekształcaniem i rozbijaniem, ze swobodnym łączeniem tekstów z różnych porządków pragmatycznych i stylistycznych. Autorzy uzyskują tego rodzaju efekty, gdy na przykład kontaminują kliszę językową czy związek frazeologiczny z odmiennymi stylowo frazami, kumulują z zamierzoną przesadą wiele językowych błędów i niezręczności w obrębie jednej wypowiedzi, wypełniają formę gatunku użytkowego nieadekwatną treścią, nakładając na siebie dwie odmienne wypowiedzi; gdy wmontowują cudzy tekst użytkowy w obcy kontekst pragmatyczny.

Proponuję wyodrębnić trzy dominujące strategie przetwarzania form nieliterackich w literaturze polskiej po 1956 roku, czyli deformację, demontaż i kontrast. Chciałabym je pokazać na kilku szczególnie wyrazistych przykładach neoawangardowych tekstów Mirona Białoszewskiego, Tadeusza Różewicza i Leopolda Buczkowskiego. Strategie eksperymentalnej literackości są w tej twórczości zasadniczym czynnikiem znaczeniotwórczym. To właśnie deformujące przetworzenie, rozbicie w demontującym geście, zaskakujące sąsiedztwo skontrastowanych form wydobywa nadrzędny sens utworu literackiego. Kontrast, deformacja, demontaż odrywają ponadto słowo od realnego użycia, a w rozluźnionej przez zabiegi literackiego przetworzenia relacji między słowem a jego desygnatem konstytuuje się odmienna funkcja ponownie użytej wypowiedzi, tworzą się nowe znaczenia.

Strategia kontrastu wiąże się regułą zestawienia ze sobą bądź nakładania na siebie form, które w realnym użyciu nie mogłyby zostać złączone, opiera się na grze znaczeniami wynikłymi z zestawienia jaskrawo odmiennych stylów mówienia. Strategia deformacji polega na zniekształcaniu formy i sensu pojedynczych słów oraz całych wypowiedzi, a także kondensowaniu w utworze negatywnych, tj. celowo błędnych, niewłaściwych, kuriozalnych zjawisk językowych. Strategia demontowania opiera się natomiast na rozbijaniu ciągłości wyrazów i spójności wypowiedzi, operowaniu ścinkami słów, wyrażeń i całych tekstów, łączeniu ich w osobliwe kompozycje. Oczywiście wskazany wyżej porządek jest jedną z wielu możliwości skonceptualizowania tej problematyki. Służy raczej wskazaniu kilku pojęć umożliwiających klasyfikację i opis omawianego zjawiska, wyodrębnieniu dominujących (lecz z pewnością nie jedynych) strategii artystycznych.

Opisane przeze mnie praktyki artystyczne pod różnymi względami łączą się w podobieństwach i zazębiają. Najmniej inwazyjna wobec struktur wypowiedzi nieliterackich jest, omówiona jako pierwsza, strategia kontrastu. Nowe znaczenie powstaje tu nie tyle przez ingerencję w cudzy tekst, ile wynika z połączenia odmiennych, nieprzystających do siebie 
form wypowiedzi. Samo w sobie kontrastowe połączenie jest efektem demontażu większych porządków wypowiedzi. Deformowanie, omówione w drugiej kolejności, można traktować jako strategię pograniczną, która łączy mechanizmy kontrastowego komponowania z mechanizmem demontowania, eksponowania procesu i rozkładu: elementy języka, poddane zabiegom deformacji, tworzą kompozycję, która określa ich charakter przez relacje zachodzące między przetworzonymi elementami. Mechanizm deformacji opiera się również na technikach demontowania, eksponowania procesu i rozpadu form wypowiedzi. Z kolei wypowiedź demontowana, ujmowana w procesie powstawania, zachowująca nieciągłą dynamikę potocznego myślenia, ujawnia swoją chaotyczną, niedoskonałą (a więc podatną na wyolbrzymienie) postać. Trzeci mechanizm dotyczy wypowiedzi najbardziej przetworzonych, bo deformowanych, rozbijanych na części, wyabstrahowanych nie tylko z pierwotnego kontekstu użycia, ale też z potencjalnie je scalających ram utworu literackiego. W swoim tekście kojarzę strategię kontrastu z twórczością Buczkowskiego, deformację - z twórczością Różewicza, a demontaż - z poezją Białoszewskiego. W twórczości tych autorów można dostrzec przykłady wszystkich wskazanych tu strategii, choć wydaje się, że w w eksperymentalnym dorobku każdego z nich dominuje inna..

\title{
Kontrasty
}

Za przykład kontrastowego zestawienia odmiennych form wypowiedzi można uznać Urodę na czasie Leopolda Buczkowskiego (1970). Jest to utwór przypominający galerię wypowiedzi z różnych okresów i źródeł, literackie studium mowy. Autor odciął cudze słowa od sytuacji mówienia i wypełnił treścią przypadkową, pretekstową i drugorzędną. Zebrane razem układają się nie w opowieść, lecz w indeks nieprzystających do siebie wyrażeń. Oto przykład sekwencji tekstów, którą otwiera rozmowa wyjęta z XIX-wiecznych rozmówek polsko-francuskich:

\begin{abstract}
Skorom się tylko dowiedział o przybyciu pani, pośpieszyłem natychmiast złożyć moje uszanowanie. Bardzo to grzecznie ze strony pana, za co dziękuję. Któż panu powiedział, że tu jestem? Ktoś wierny pani, któregom spotkał na zakręcie ulicy. Czy można się spodziewać, że pani z nami przez jakiś czas zabawi?
\end{abstract}

(Buczkowski 1970: 5)

Rozmowa, widziana jako odrębna wypowiedź, wyraża powagę, grzeczność i wzajemny szacunek tych, którzy w niej uczestniczą. Zestawiona z jednej strony ze współczesną, błahą, potoczną rozmową między domownikami, a z drugiej — z medyczną definicją mózgu, wyabstrahowaną z kolei z podręcznika do anatomii, nabiera innych znaczeń i staje się werbalnym eksponatem francuskiej mieszczańskiej obyczajowości. Umieszczona w kontekście zasadniczo współczesnym (tekstowa „akcja” tego początkowego fragmentu Urody na czasie rozgrywa się w XX wieku), nie tyle obrazuje minioną mentalność, odzwierciedloną w tekście użytkowym tego okresu, ile celowo razi przestarzałością archaicznych form językowych („skorom”, „któregom”, „złożyć uszanowanie”). Zresztą nie tylko one przywodzą na myśl minioną epokę, to również typ gorliwej atencji, jaką mężczyzna darzy kobietę. Frazy „skorom się tylko dowiedział” i „pośpieszyłem natychmiast złożyć moje uszanowanie” z perspektywy współczesnej mogą się wydać nie tyle uprzejme, ile nadmierne i przesadne, trącące egzaltacją, która nie przystaje do komunikatu nastawionego na okazanie pokornej atencji drugiej osobie. 
Fragment rozmówek poprzedza oddzielone od niego wymowne pojedyncze zdanie: „Nie jest kiedy drugie jest”, a za nim pojawia się scena oględzin domu i rozmowa z jego mieszkańcami, utrzymana w rejestrze potocznego języka mówionego. Rozmowa między bohaterami - niepoprzedzona wprowadzeniem narratora, którego funkcja jest niemal całkowicie zredukowana, a narrację zastępuje układ cudzych tekstów — przeistacza się nagle w potoczny dialog anonimowych bohaterów, złożony jakby z różnych kwestii, które spaja nie tyle sytuacja rozmowy, ile temat zdrowia. Niektóre kwestie zjawiają się jakby niezależnie od jej toku.

Mówią, że pijawki zdrożały.

Ja kazałem sobie przywieźć ze wsi i mam ich zawsze zapas.

Proszę pana, na wszystko umrzeć można.

Cóż zażyłaś dla pozbycia się kataru?

Trzymałam się ciepło, a przede wszystkim nogi, i piłam krople na piersi.

Ona nie może wcale mówić. To rzecz okropna dla tak dobrej śpiewaczki.

Czy znasz coś nieprzyjemniejszego jak mieć katar?

Czego płacze to dziecko?

Ma rżnięcie.

Kaszlesz bardzo. Bolą ciebie piersi?

(Buczkowski 1970: 8)

Zapewne ten pretekstowy temat zdrowia, bo z pewnością nie prawdopodobieństwo komunikacyjne, skierował niespodziewanie narrację na wycinek z poradnika neurochirurgii czy medycyny sądowej:

Następuje śledzenie samego mózgu, nie wyjmując go z czaszki - czy jest jędrny, czy wypełnia czaszkę [...]. Sierp błony twardej, processus falciformis durae matris, odcięty od crista galli ossis ethmoidei i odsunięty ku tyłowi na os occipitis. Wszystko zbadane aż do centrum semi avale, używając do tego noża szerokiego i ostrego [...] Badanie substancji corticalis et medullaris na kolor. Śledzenie wielkiego mózgowego spojenia, corpus callosum, czy jest zupełnie białe, czy nie znajdują się na nim czerwone kropelki, czy nie daje się w nim czuć pluskanie. Czy nie uszkodzone septum pellucidum. Plexus chorideus wyjmuje się za pomocą palca i trzonka noża i uważa się, czy nie znajdują się tu hydatyny i piasek. (Buczkowski 1970: 9)

Jedynym komunikacyjnym uzasadnieniem tego nietypowego zestawienia potocznej, rodzinnej rozmowy, XIX-wiecznej konwersacji i wyspecjalizowanej medycznej instrukcji jest temat zdrowia, który mógł je połączyć w abstrakcyjną sekwencję wypowiedzi na prawach artystycznej logiki absurdu. Celem tego zestawienia jest uprzedmiotowienie i skompromitowanie słowa (Nycz 1978: 108; Owczarek 2014: 137), znoszenie jego informacyjnej wartości, wiarygodności jego przekazu, jego sprawczości lub urody (w zależności od tego, jaką funkcję pierwotnie pełni). Fragmenty, które sprawiają wrażenie zachowanych w całości, wprost przeniesionych w ramy osobliwej narracji, nienaruszonych poetycką ingerencją, zostają ośmieszone w równej mierze jak fragmenty, które podmiot zniekształcił wedle reguł groteski (w czym zresztą można się dopatrywać strategii deformowania). Nadrzędny podmiot tego utworu modyfikuje ich znaczenie przede wszystkim przez dobór celowo niewłaściwego kontekstu wypowiedzi, przez sam kontrast zestawienia z formą jaskrawo odmienną, a więc wpływa na nie niejako z zewnątrz. Wedle słów Buczkowskiego: „kształt i symbolika obrazu rodzi się 
«pomiędzy» jego składnikami” (cyt. za: Kirchner 1996: 101), a więc poza sensem odrębnej wypowiedzi, między jedną formą tekstową a drugą, między jej znaczeniem literalnym a konotowanym, między wypowiedzią a jej wyobrażoną formą źródłową.

Fragment o rozkrawaniu mózgu oczywiście uchyla fabularną zasadność czy autentyzm sceny kurtuazyjnej rozmowy, a znaczenia komplikują się, a więc nabierają artystycznych walorów, przez skontrastowanie dwóch modalności: żarliwej grzeczności rozmówców z obojętnym chłodem neutralnej instrukcji. Z kolei swobodna rozmowa w kręgu rodzinnym, która znalazła się między jedną a drugą formą, rozsadza powagę ich obydwu. Z jednej strony czyni fragment staroświeckich rozmówek obiektem parodii, demaskując fasadowy charakter konwencjonalnego mówienia. Z drugiej wyśmiewa hermetyczną mowę podręcznika medycznego, choć równie dobrze można uznać, że to podręcznik medyczny wyjaskrawia przywary rozmówców, toczących mało konkretną i niezdyscyplinowaną rozmowę w porównaniu do treściwego opisu budowy mózgu. Żadna wypowiedź nie jest w Urodzie nadrzędna względem innej, każda spełnia tę samą funkcję wyostrzania właściwości sąsiadującej z nią mowy (Bukowiecka 2019).

\title{
Deformacje
}

Druga strategia - deformowania - opiera się na zabiegach celowego „pogarszania” mowy, obniżania jej poziomu, wyostrzania jej negatywnych jakości i zjawisk (związanych z eksponowaniem błędów i niezręczności); jest to rodzaj transformacji, która, kompromitując słowo, pozwala utrzymać je w stanie podejrzenia (Sławiński 2001: 300). Ale też wydobywa właściwości mówienia. Oto przykład strategii deformowania w tekście Tadeusza Różewicza z tomu Kupkota w worku:

\begin{abstract}
mimo że jest luty leżę rozłożona na pełnej kwiatów łące przez moje ciało płynie strumień który niesie niepowstrzymany potok słów [...] marzę o papie priapie hymenie i czuję ciężar pustki bytu w niebycie i odbycie w zbycie liczę że w tym roku i ja stanę w szranki z tą Jellonek w czym ona lepsza ode mnie albo naszych dziewczyn z teatru dziurdziowie podmalować to jednak trzeba walką w rewolucji pomarańczowej szpinakowej zielonej oddałam się dziś cała pisaninie sprawia mi to czasem uczucie zbliżone do cyberorgazmu w pokoiku erotycznym zamkniętym na kłódkę słowo mi wychodzi ze słowa jak te flopy z popo nie chcę tej powieści! napiszę analizę najsłynniejszego erotyku fądesieklu w Krakowie czy też gdzieś na skalnym podhalu [...] do roboty dziewczyno przyj przyj przyj ten facet nazywał się dość dziwnie najpierw przerwa potem Tetmajer i na początku Kazimierz a jego wiersz lubię przecinek kiedy kobieta zrobił światową furorę i był hitem [...] oczywiście język Tetmajera przerwy nie jest już naszym językiem i przypomina trochę jojcego Bralczyk jeden wie jak to się odmienia [...] no więc jojce wielkie jojo! $Z$ tym swoim Blumem co to wsadził nos w zafajdane barchanowe majtki Molly czy innej Dolly i pomyśleć że taki fineas Ganse uchodzi za arcydzieło światowej literatury ja majtek nie noszę i oddam się sama na aukcję nik nike nominowali mnie z Rysiem Tadziem do niki był tam też Jarek Marek ale bocian rażony grypą spadł między moje nogi jak bym była jakąś Danae albo ledą. (Różewicz 2008: 14-15)
\end{abstract}

Widzimy tu słowotok egzaltowanej postaci aspirującej do miana literatki. Jej rojenia o literackiej sławie odzwierciedlają się w nadziei na nominację do nagrody Nike i narcystycznej samoocenie, która pozwala bohaterce ustawić się w jednym rzędzie z Jamesem Joycem, Elfriede Jelinek i Kazimierzem Przerwą-Tetmajerem. Poetyckie imaginarium bohaterki wypełniają zagadnienia literatury młodopolskiej (wpływy fin de siècle, twórczość Tetmajera, powieść Orzeszkowej) i tematyka seksualno-porodowa (motywy cyberorgazmu, erotycznego pokoiku, 
majtek Molly Bloom, mitologiczne postacie Priapa i Hymena, parcie jako korelat pisania, „flopy z popo” - zdeformowany tytuł wiersza Zbigniewa Sajnoga Flupy z pizdy, opublikowanego w „Brulionie”). Zresztą niemal wszystkie nazwy własne zostały tu zdeformowane: Jellonek to Jelinek, Blum to Bloom, Jarek Marek to Jarosław Marek Rymkiewicz, a „jojce wielkie jojo!” to James Joyce. Skoro pojawił się Joyce, to tajemniczy tytuł fineas Ganse należy rozszyfrować jako Finnegans Wake, a z dwojga imion przywołanych tuż obok: Molly i Dolly — wybrać raczej Molly, bohaterkę Ulissesa, choć z kolei Dolly (sklonowana ongiś owca) pasuje do przywołanego w tekście porządku autentycznych wydarzeń z początku XXI wieku (pomarańczowa rewolucja, problem ptasiej grypy). Przekształcenie nazw własnych można by złożyć na karb ignorancji i głupoty wypowiadającej się tu bohaterki, choć ich natężenie i mocna deformacja zapisu przywodzą na myśl celową, groteskową przesadę nadrzędnego podmiotu i jego ogólną intencję wydobycia językowego komizmu czy parodystycznego żartu.

Fragment Kup kota w worku Różewicza to wyimek z obszernej narracji utrzymanej w tym samym stylu i tonie. W całym utworze rejestr polszczyzny literackiej dominuje w kilku zaledwie zdaniach, które zresztą stopniowo nasycają się potocznością i wulgaryzmami. Podstawowym rejestrem języka jest w tym zbiorze zasadniczo potoczny język mówiony, polszczyzna literacka nie stanowi tu nawet punktu odniesienia. Nadrzędny podmiot, zarządzający głosami wypowiadających się w Kup kota w worku postaci, nadbudowuje więc językowe deformacje na potocznej mowie, wobec której zachowuje dystans, tj. raczej nie utożsamia z nią swego głosu.

Poza zabiegiem zniekształcania nazw własnych warto również zwrócić uwagę na innego rodzaju lingwistyczne deformacje, np. słowotwórczo-paronomastyczne przekształcenie słowa „byt”: „czuję ciężar pustki bytu w niebycie i odbycie w zbycie” — w którym na sformułowane raczej serio wyznanie bohaterki nakłada się prześmiewcza perspektywa podmiotu; to raczej jemu trzeba by przypisać żartobliwe skojarzenie „odbytu” z „bytem” i długie wyliczenie (pozornie) spokrewnionych wyrazów, odrywające owo wyznanie od reguł prawdopodobnego w realnych okolicznościach komunikatu. Chwyty udziwniające, deformujące wypowiedź wyjściową (którą można sobie wyobrazić jako kwieciste, egzaltowane wyznanie grafomanki, oszpecone niezamierzonymi niezręcznościami stylu) nadają jej status słowa artystycznego, metaliterackiego czy metajęzykowego; komplikują również tożsamość podmiotu — w wypowiedzi tej, by zacytować Bachtina, „cudza mowa ma [...] podwójną ekspresję — własną, to znaczy cudzą, oraz ekspresję wypowiedzi, w której mowa ta znalazła schronienie" (1986: 393). Na poziomie metajęzykowym narracja — za sprawą deformacji — problematyzuje i wyjaskrawia właściwości chaotycznej logorei.

Podobne deformujące (ale i demontujące) język nieliteracki zabiegi można odnaleźć w wielu wcześniej wydanych dziełach Tadeusza Różewicza. Bogatym w przekształcenia tekstem jest zwłaszcza Tarcza zpajęczyny. Ale i w drobniejszych utworach nie brakuje twórczych transformacji tekstów gotowych. W wierszu Non-stop-shows z 1963 roku autor podejmuje problem zetknięcia wartościowej kultury z intelektualną i estetyczną „sieczką” marnych tekstów i błahych rozrywek współczesności. Poza bogatą sferą cudzej mowy, wykorzystanej ironicznie, parodystycznie, polemicznie, wypowiada się również we własnym imieniu, stawiając diagnozę stanu kultury swoich czasów: „Żeby pisać w naszych czasach / trzeba się ograniczyć zgodzić zamknąć / ogłuszyć / dawniej pisano z nadmiaru / dziś z braku” (Różewicz 2006: 405). Powracająca tu i w wielu innych utworach formuła „das Spiel mit den Möglichkeiten”, odnoszona ironicznie do kultury współczesnej, ma w kontekście tej deklaracji szczególnie cierpką wymowę. 
Deformacja cudzej mowy przybiera w tym utworze kilka stopni. Najpierw pojawia się zmodyfikowany cytat (?) z recenzji Lolity Nabokova. Oczywistym wskaźnikiem cytowania jest zachowany przez autora (a być może sfingowany, wprowadzony dla efektu przytoczenia) cudzysłów. Formę recenzji prasowej przywodzi na myśl również otwierająca cytat dziennikarska klisza o książce jako literackim wydarzeniu (akurat w przypadku Lolity zasadna):

\section{Lolita Recenzja}

„Niebywały sukces Lolity to chyba najbardziej

sensacyjne wydarzenie literackie ostatniego

dziesiątka lat. Smak Lolity nie leży w opisach

Miłość w średnim wieku z dwunastoletnią dziewczynką... Lolita jest symbolem

cywilizacji amerykańskiej: młodej prężnej

wulgarnej niedojrzałej..."

(Różewicz 2006: 406-407)

Mimo znaków przeniesienia cudzego tekstu w obręb wiersza widzimy tu ślady poetyckiej ingerencji: delimitacja wierszowa, deformująca tekst, tj. rozbijająca związki wyrazowe (najbardziej / sensacyjne, ostatniego / dziesiątka) - nadaje wypowiedzi inną niż pierwotna funkcję; tekst traci znaczenie recenzji, a zyskuje status poetyckiej krytycznej analizy dyskursu dziennikarskiego. Sprzyja temu ponadto deformujący zabieg "pogarszania” mowy; podmiot poetycki celowo wprowadza tu błędy i niezręczności („ostatni dziesiątek lat” zamiast „ostatnie dziesięć lat” lub „ostatnie dziesięciolecie”). Inny przykład to fragment „smak Lolity nie leży w opisach”, ucięty w pół, więc z punktu widzenia funkcji recenzyjnej bezsensowny. Mgliste znaczenie określenia „smak Lolity”, a także pokraczna semantyka i składnia sformułowania „nie leży w opisach” to skumulowany w kilku słowach obraz dziennikarskiej grafomanii, wyjaskrawionej przez poetycki zabieg deformacyjnego spiętrzenia błędów językowych. O ile przykład ten można traktować jako fragment nieudolnego tekstu użytkowego, o tyle dalsze przykłady przywodzą na myśl bardziej radykalną artystyczną ingerencję w cudze słowo:

\section{Garaż śmierci West Side Story Lolita \\ Zawrót głowy Lolitę widziałem w Monachium \\ Lolita Ta lolita to bardzo nudny długi \\ Film z doskonałym aktorem który jest zły \\ w tym filmie lolita to taki sopelek \\ lodu dziewczynka bez zarostu pod pachami \\ jak laleczka On docent czy coś w tym rodzaju}

(Różewicz 2006: 407-408)

Tu z kolei niespodziewanie łączą się w jednej sekwencji cztery tytuły filmów (Garaż śmierci, West Side Story, Lolita, Zawrót gtowy), wymienione ad hoc bez uchwytnego porządku, a fragmentu nie spaja żadna gatunkowa rama tekstowa (poza nieostrą kwalifikacją "paplaniny”, na którą wskazuje tak pustosłowie określeń typu „czy coś w tym rodzaju”, jak bezsensowna, wewnętrznie sprzeczna opinia „film z doskonałym aktorem który jest zły w tym filmie”). Ośmieszoną przez te błędy „gadaninę” wytrąca z mimetycznego przytoczenia - poza delimitacją wierszową - wykaz tytułów filmowych i lingwistyczny zabieg instrumentacji dźwiękowej („Lolita Ta lolita”). Jeszcze dalej podmiot utworu przytacza — bez żadnego już odniesienia 
do pragmatyki językowej i reguł komunikacji — indeks zagranicznych szyldów, z pociętymi w wierszu i przemieszanymi wyrazami:

\author{
Monachium Royal-Theater \\ Monachium München \\ Italia Bar Harem-Bar Haremsfrauen \\ Bongo Bar Tai-Tung Beste Köche aus Chungking \\ La bohème Schaschlik Bockwurst Riesenwurst \\ Intermezzo Striptease à la Paris \\ Moulin Rouge Bomben Variétéprogramm \\ Die Zwiebel Lola Montez Bar Pique Dame
}

(Różewicz 2006: 408)

I tak dalej. Łączą się tu nazwy teatrów i barów z różnych części świata z nazwami znanych niemieckiej gastronomii rodzajów kiełbas, a także określenia kultury rynsztokowej („streaptease”) z wysokoartystycznymi pojęciami („intermezzo”). W jednym wersie podmiot liryczny zestawia słowa niemieckie, włoskie, angielskie i francuskie, w drugim spotykają się niespodziewanie rzeczownik pospolity „cebula” z nazwiskiem tancerki i nazwą baru. Słowa, wyjęte z wielu odmiennych realiów (geograficznych, kulturowych, językowych), rozmontowane i złożone w osobliwy indeks, stają się jakby werbalnymi odpowiednikami jaskrawo rozświetlonych neonów, „napstrzonych” na głośnej, ruchliwej ulicy. Słowa nie podlegają tu regułom wiązania w linearnej narracji, nie łączą się w logiczne i semantyczne związki; stają się jakby rzeczami. Ostatni cytowany fragment Non-stop-shows ilustruje dwie strategie literackie: deformację, bo podmiot zniekształca tu tok wypowiedzi, oddając w nadmiarowym, przytłaczającym rejestrze nazw doświadczenie informacyjnego natłoku. I demontowanie, bo z najmniejszych elementów miejskiej logosfery układa nową całość i znosi w utworze autonomię języka literackiego, zastępując go nawet nie wypowiedzią nieliteracką, lecz indeksem nazw własnych, jeszcze dalszym od wzorca mowy artystycznej. Radykalność literackiego demontażu Różewicza polega też na tym, że ten utwór, składający się wszak na dorobek polskiej poezji, wypełniają wyrazy z różnych języków obcych.

\title{
Demontaże
}

Inny wyrazisty przykład demontowania wypowiedzi nieliterackich przynosi twórczość Mirona Białoszewskiego. W wydanym niedawno zbiorze niepublikowanych tekstów (zwłaszcza poetyckich) znalazł się np. utwór życiowymyst:

przez sześć lat w instytucji donosiła dokładnie ze swego życia jak idzie o córce z mężem z ropą za uszami wnuczek rośnie drugiej rosła tkanka gruszki w sadzie przywoziła jedli wszyscy czasem ciężko zasłaniała się na szwagra mdlała nigdy się nie pomyliła bo wszystko wyssała razem z malarią przez którą jak pojechali ratować to się wydało bo nie mieszkała a nie wyszła córka ale ona za mąż sama w nocy chodziła po ulicy z tego lekkiego chleba te gruszki chociaż w dzień suszyła pocztówki a trzecie życie to to, to żadnego nie miała a może miała cztery ale żadne niefaktyczne. (Białoszewski 2017: 187)

Tytuł tego tekstu - zyciowymyst - dobrze oddaje jego specyfikę. Jego pierwsza połowa podobnie jak pierwsze lekturowe wrażenie — wskazuje, że mamy tu do czynienia z „życiem”, żywym, zasłyszanym słowem, nieco bezładną relacją z czyichś rodzinnych perypetii. Wystar- 
czy jednak wczytać się głębiej, natknąć na celowe zakłócenia toku wypowiedzi, spowodowane demontowaniem zdań i sekwencji opowieści, by zorientować się, że tekst jest raczej „wymysłem”, tj. efektem zabiegów literackich, które z jednej strony podważają jego mimetyczną wiarygodność, z drugiej - nakładają na wypowiedź warstwę dodatkowych, ściśle literackich znaczeń i wartości. Brak znaków interpunkcyjnych wprowadza tu sporo zamierzonych semantycznych wieloznaczności przez demontowanie porządku zdania. Nie wiadomo, czy zgodnie z informacją we fragmencie: „drugiej rosła tkanka gruszki w sadzie przywoziła” jakiejś drugiej postaci urosła tkanka? Czy mowa o tym, że urosła tu tkanka gruszki? Czy „gruszki” to przydawka „tkanki” (przywodząca na myśl obraz zgoła abstrakcyjny)? Czy jako odrębną sekwencję znaczeniową należy traktować raczej sformułowanie "gruszki w sadzie”, skądinąd językowo poprawne? Można również uznać, że osobną semantyczną całostkę tworzy tu sekwencja wyrazów "gruszki w sadzie przywoziła”, choć nie wydaje się ona logicznie przejrzysta (inaczej niż np. „przywoziła gruszki z sadu”).

W dalszym toku tej narracji pojawia się fragment bardziej skomplikowany; sprawia bowiem wrażenie, jakby powstał w wyniku przemieszania elementów kilku zdemontowanych zdań: „wszystko wyssała razem z malarią przez którą jak pojechali ratować to się wydało bo nie mieszkała a nie wyszła córka ale ona za mąż sama w nocy chodziła po ulicy z tego lekkiego chleba te gruszki chociaż w dzień suszyła pocztówki a trzecie życie to to, to żadnego nie miała”. Nie wiadomo, co mianowicie wyssała tajemnicza „ona”, bohaterka tej „patchworkowej” opowieści. Gdzie nie mieszkała, czy suszyła gruszki, czy pocztówki (ale na czym miałby polegać proceder suszenia pocztówek?), z czym wiąże się jej trzecie życie i czym jest. Takie pytania mógłby stawiać serio czytelnik szukający wartości informacyjnej w przekazie tego tekstu. Wiadomo jednak, że meritum wypowiedzi jest raczej pretekstowe, a zabieg przemieszania ściętych, informacyjnie niepełnych fragmentów wypowiedzi ma raczej oddać celowo wyjaskrawiony efekt rwanej chaotycznej opowieści. Lub wrażenie odbioru wielu rozmów słyszanych naraz w gwarnym miejscu pełnym wypowiadanych jednocześnie kwestii wielu osób.

W najdziwniejszej, najbardziej złożonej sekwencji wyrazów „nie wyszła córka ale ona za mąż sama w nocy chodziła po ulicy” wymieszano kolejność słów w zdaniu, którego postać wyjściowa mogła wyglądać tak: „córka nie wyszła za mąż, ale ona w nocy chodziła sama po ulicy”. Wersja „niewłaściwa”, literacko wszakże ciekawsza, przynosi - poza efektem mowy całkiem zdezintegrowanej, odciętej od reguł komunikacyjnego prawdopodobieństwa - również semantyczną grę z frazeologizmem „wyjść za mąż”, która (niczym w poezji Nowej Fali) rozbija idiomatyczne znaczenie tego wyrażenia przez udosłownienie jego elementu („wyjść”).

Bywa, że demontowanie przybiera w poezji Białoszewskiego bardziej radykalną postać, zwłaszcza wtedy, gdy dotyczy rozbijania pojedynczych słów z porządku nieliterackiej mowy. W następnym utworze z tego tomu, Nowelat, rozmontowane cudze wypowiedzi przeistaczają się w werbalną sztukę niefiguratywną, niemal całkowicie zacierającą swoje znaczenie.

Nowelat

$\begin{aligned} & \text { dwie wych. Fibzie } \\ & \text { sanatorjadzie } \\ & \text { cięce się }\end{aligned}$
Jedna na łamach skruchy
kolczasty choinki kleci spo-
łańcuchność




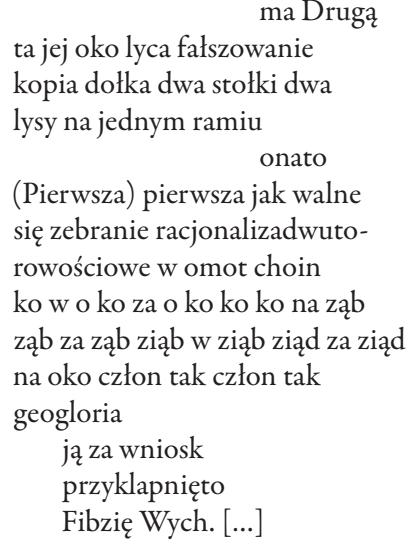

(Białoszewski 2017: 187-188)

Na nadrzędną tematykę tego znaczeniowo niejasnego utworu naprowadzają jedynie poszlaki: podpis pod wierszem „Wwa 5 stycznia 1961”, pojedyncze zachowane w całości słowa: „choinka”, „ziąb”, „tańczyć” i wyrazy rozbite czy zniekształcone, takie jak „społańcuchowość” (od łańcucha?), „geogloria” (słowo z kolędy?) i tytułowe „Nowelat” (od „nowych lat”, a więc Nowego Roku?). Układają one — z kilku zaledwie odłamków — obrazek z okresu świąteczno-noworoczno-karnawałowego. Rysuje się tu dialog dwóch „wych.” (wychowaczyń?) w sanatorium („sanatorjadzie cięce się”), prowadzących zajęcia z dziećmi. Na to wskazuje wyraźniej fragment „tańczyć uczyć dzieci rwę”, zresztą demontujący związek wyrazowy w orzeczeniu złożonym „uczy tańczyć”, i mniej wyraźnie fraza „sanatorjadzie cięce się”, sklejająca w nowym, literackim „słowotworze” skrawki rozmontowanych uprzednio słów: sanatorium (stąd „sanatorj”), jechać (stąd „jadzie”), cięcie i wreszcie „dziecię”, mniej widoczne, bo rozcięte na pół: „sanatorjadzie cięce się”. W dalszym fragmencie słowa są całkiem rozbite, jakby podmiot przedkładał brzmieniową wartość ich pojedynczo rozsypanych głosek nad możliwe znaczenie zachowanych w całości wyrazów: „choin ko w o ko za o ko ko ko na ząb ząb za ząb ziąb w ziąb ziąd za ziąd na oko człon tak człon tak".

Utwory eksperymentujące z formami wypowiedzi użytkowych zazwyczaj wypełnione są wyłącznie materią cudzego słowa, a więc i całkowicie redukują sferę neutralnej wypowiedzi, na której tle mogłyby się wyróżniać wypowiedzi ekscentrycznie odmienne, rażąco nieliterackie. W wielu przypadkach językowe artefakty, pozbawione narracyjnego spoiwa, niejako mówią same za siebie, a podmiotowa aktywność konstytuuje się w samym sposobie użycia słowa, ujawniając metaartystyczny zamysł utworów.

Zabiegi literackie są w tej sytuacji niejako sferą niebezpośredniej artykulacji krytycznego odniesienia autorów do przetwarzanego języka. Jest to więc krytyka implikowana przez kontrastową kompozycję, deformujące przetworzenie, rozbicie formy tekstu, pozornie swobodne gospodarowanie jego elementami. Głos eksperymentującego z mową podmiotu krystalizuje się zawsze w sferze „pomiędzy”: w rozluźnionej relacji słowa i jego desygnatu, między jedną a drugą formą językową, między gatunkiem przetworzonym a jego inwariantem, między urywkiem czyjegoś tekstu a jego wyobrażoną całością, między wypowiedzią zdeformowaną 
a jej wariantem nienaruszonym. Znaczenia wypracowują się w relacji odmiennych, skontrastowanych form, konwencji i stylistyk. Punkt odniesienia określający wyjściowy wariant przetworzonej wypowiedzi jest poza tekstem literackim. Literackość przenosi cel i zakres swoich działań z poziomu stylu na poziom stylizacji, z poziomu narracji na poziom konstrukcyjnych działań, zmierzających do ułożenia gotowych tekstów.

\section{Modernizm - ciąg dalszy?}

Eksperymentalną twórczość lingwistyczną ${ }^{1}$ po 1956 roku proponuję traktować jako specyficzną odmianę modernizmu. Wyróżnia się ona na tle młodopolskich i międzywojennych tendencji modernistycznych odmienną od nich koncepcją języka literackiego. Twórczość, która w ciągu ostatnich sześćdziesięciu lat artystycznie transformuje mowę nieliteracką, jest oczywiście wewnętrznie zróżnicowana, jednak nie na tyle, by zaniechać próby syntetyzowania jej właściwości i określania ram nadrzędnego dla niej porządku, który pozwoliłby wyodrębnić tak zdefiniowaną literaturę jako okres rozwoju modernizmu.

Za niektórymi badaczami tego zjawiska pojmuję go szeroko jako formację kulturową, obejmującą nowatorską literaturę od Młodej Polski po współczesność, co oznacza, że w zakresie tego pojęcia mieszczą się również takie zjawiska jak awangarda ${ }^{2}$ i postawangarda. Modernizm w tym ujęciu jest rozumiany jako formacja oparta na współistnieniu i dialogowaniu sprzecznych estetyk i stanowisk, koncepcji nowoczesności i antynowoczesności, wyróżnia się aspiracjami transgresyjnymi pisarzy (tematycznymi, gatunkowymi, aksjologicznymi itp.), wykracza poza normy estetyczne i społeczne (Bolecki 2012: 8). Tym, co pozwala wpisać współczesne eksperymenty z językiem nieliterackim w ogół tendencji modernistycznych, jest właściwe owym praktykom i zarazem typowe dla modernizmu przekonanie o nieuchronnej petryfikacji i schematyzacji języka, jego właściwościach z jednej strony alienujących, stawiających opór możliwościom wyrazu, z drugiej warunkujących myślenie i komunikację (Nycz 2013: 60). Wczesną fazę formacji Ryszard Nycz charakteryzuje tymi słowy:

coraz ostrzejsza i powszechniejsza staje się w tym okresie świadomość nieuchronności uwikłania w język, upośredniającego nasz kontakt ze światem wewnętrznym i zewnętrznym, a także rozpoznanie jego aktywnej roli (czynnika kształtującego obraz rzeczywistości i stąd oddziałującego na rezultaty poznania). Coraz częściej dostrzega się także siłę oporu, jaki język stawia pragnieniom i możliwościom wyrazowym podmiotu [...]. Wynikiem zaś jest odkrycie jego ideologicznej i alienującej władzy, płynącej z odkrywanych przez język ról: stronniczego pośrednika oraz współkonstruktora obrazu społecznej rzeczywistości. (Nycz 2013: 60)

Istotnym składnikiem tej formacji jest „modernistyczny syndrom petryfikacji języka” (Nycz 2013: 75); odkrycie mowy, jak pisze badacz, zarażonej szablonem, żyjącej obsesją kliszy (75). Nieufność wobec języka, nasilona w okresie Młodej Polski, w dużej mierze określiła charakter nowatorskich tekstów literackich powstałych w XX wieku.

Wedle Ryszarda Nycza literatura nowoczesna, której specyfikę określa negacja kultury popularnej czy masowej z jednej strony i zaangażowanej czy zinstrumentalizowanej z drugiej,

1 Mam tu na myśli nie poezję lingwistyczną, lecz ogół tendencji do wzmożonego zainteresowania językiem w twórczości tego okresu.

2 Relacja awangardy i modernizmu to złożony problem, który omawia, odnosząc się do rozmaitych koncepcji łączenia tych dwóch pojęć, Joanna Orska w książce Przetom awangardowy w dwudziestowiecznym modernizmie (2004). 
z czasem - w XX wieku, w dobie ponowoczesnej ${ }^{3}$ — zasymilowała te zewnętrzne opozycje, cechy konkurencyjnych form pisarstwa; w efekcie stały się one elementami wewnętrznej charakterystyki literatury ponowoczesnej (Nycz 2012: 203).

Rezultatem tego procesu — pisze badacz — było wyparcie zasady ekskluzji (definiowania swej odrębności przez wykluczanie i odróżnianie) przez zasadę inkluzywności (definiowania swej swoistości przez współistnienie i wzajemne związanie heterogenicznych reguł, konkurencyjnych tradycji, alternatywnych poetyk). (Nycz 2012: 204)

Jak wskazuje Ryszard Nycz, ta ewolucja skutkuje wypracowaniem trzech generalnych tendencji. Pierwsza to zmiana ontologicznego statusu literatury. W drugiej połowie XX wieku zasadniczo nie definiują jej immanentne cechy wzorcowego dzieła literackiego. Oznacza to przejście „od prymatu esencjalnego rozumienia literatury do prymatu koncepcji literatury jako instytucji” (Nycz 2012: 204). Druga tendencja: zmienia się status literatury „jako przedmiotu literaturoznawczego poznania”. Jest ona rozpatrywana już nie jako „normatywny system gatunków i rodzajów mowy, specyficzny system reguł językowo-estetycznych, lecz jako dziedzina dyskursu językowego, praktyki skodyfikowanej społecznie i kulturowo" (2012: 204). Trzecia tendencja polega na zmianie pragmatycznego statusu literatury. W rezultacie jej konteksty (kulturowe, historyczno-polityczne, psychospołeczne) stają jej istotnym wewnętrznym składnikiem, a nie zewnętrznym obszarem w stosunku do autonomicznego pola literatury (Nycz 2012: 204-205).

Wszystkie te rozpoznania określają specyfikę opisywanych przeze mnie przemian literatury, której wartość wynika z inkluzywnego łączenia rozmaitych poetyk i reguł wysłowienia: nieliterackiego, ale i literackiego, np. sparodiowanych wzorców literatury autonomicznej, elitarnej, zaangażowanej i popularnej (by wymienić wskazane przez Nycza modele dyskursów literatury nowoczesnej). Uformowanie takiej jej postaci wiąże się z zanegowaniem wzorca autotelicznej, oderwanej od społecznych zjawisk literackości czy normatywnego postrzegania literatury jako sztuki elitarnej. Literatura staje się dziedziną dyskursu językowego, a zjawiska społeczne, psychologiczne, polityczne - utrwalone w języku — stanowią jej podstawowy budulec.

Patrząc w szerszym planie na historię literatury XIX i XX wieku, można by, nawiązując do badań Michała Głowińskiego, wskazać kilka zasadniczych przemian w rozumieniu języka literackiego. Nie bez uproszczeń, ale moim celem nie jest, skądinąd niemożliwe, przedstawienie historycznoliterackich niuansów dwóch wieków w dwóch słowach, lecz wskazanie pewnych ogólnych konceptualizacji mowy artystycznej i potocznej. Na tym tle widać specyfikę ostatniej fazy modernizmu. Problem omawiany w tekście Michał Głowiński stawia w tytule swojej rozprawy: Czy literatura może być wzorem mowy? — i omawia warunki tej zależności. Badacz wychodzi od omówienia przypadku harmonijnego zrównania czy utożsamienia języka literatury z językiem potocznym (rozumianym przez niego w całym tekście jako neutralna mowa ogólna, nie zaś język nacechowany kolokwialnie) w dziewiętnastowiecznym realizmie. Jak dowodzi uczony, idea tego zrównania, wiążącego się z określeniem roli języka literackiego jako wzorcowej mowy potocznej, spełniła się, ponieważ język ówczesnej literatury odzwierciedlał potoczną mowę inteligencji (stanowiącej wówczas większość czytelników), a inteligencja wzorowała swój język na literaturze (Głowiński 1997).

3 Ryszard Nycz uznaje, że modernizm trwał w literaturze polskiej do lat 60. XX wieku. Badacz rozgranicza w opisach współczesnej literatury polskiej pojęcia nowoczesności i ponowoczesności (zob. Nycz 2000, 2012). 
Tym realistycznym wartościom: harmonii i równowadze, aprobatywnemu podejściu do języka literatury oraz jego przezroczystości można przeciwstawić wartości modernistyczne (choć sam autor nie odnosi się w ogóle do pojęcia modernizmu): konflikt, negację i — przywołuję termin badacza — widoczność języka. Jak wskazuje Głowiński, owa harmonia języka literackiego i potocznego załamała się wraz z nastaniem naturalizmu, a w związku z tym problem literatury jako wzorca mowy zaczął się zarysowywać inaczej (1997: 118).

Równowaga ta została zachwiana bądź dlatego, że literatura zaczęła się fascynować tym, co można by nazwać tworzeniem mowy własnej, w jakiejś przynajmniej mierze niezależnej od standardów mowy potocznej, przeto wzmożoną, zagęszczoną poetyckością, bądź z tej racji, że otworzyły się przed nią możliwości naśladowania wszelkich gatunków i odmian mowy [...]. (Głowiński 1997: 118)

W połowie XX wieku w historii literatury polskiej sforsowano wariant niewydarzonego realizmu — socrealizm, który postulował podobne do XIX-wiecznego założenie harmonijnej równowagi między językiem literackim i potocznym, a więc również zmierzał do zrealizowania koncepcji języka literackiego jako wzorca mowy — sformalizowanej i koturnowej. O ile jednak realizm z prawdziwego zdarzenia opierał się na harmonii aprobowanej, a co się z tym wiąże, język literacki był faktycznie uznawany za wzorcową postać języka ogólnego, o tyle socrealizm oznaczał harmonię pozorną i pozorowaną, narzuconą, opresyjną i antywzorcową, tym bardziej więc gwałtownie odrzuconą i zanegowaną w chwili, gdy został zniesiony.

W reakcji na dwa tak różne typy realizmu wykrystalizowały się odmienne formy modernizmu. Modernizm końca XIX wieku i początków XX oczywiście niejedno ma imię i nie jest, rzecz jasna, jednym porządkiem, lecz rozwidla się na wiele nurtów, ale zasadniczo można o nich wszystkich powiedzieć, że cechują się „widocznością języka”, jego „ekskluzywną odrębnością” względem mowy ogólnej, autotelicznością przedstawienia i rozluźnioną referencyjnością (zob. Kluba 2014). Jest to twórczość, która, najogólniej mówiąc, operuje mową oryginalną, poetycką i swoistą oraz czyni drugorzędną kwestię odniesienia do rzeczywistości.

Twórczość modernistyczna drugiej połowy XX wieku, choć podobnie jak wcześniejsza czyni język swoim centralnym zagadnieniem, ma odwrotne założenia: operuje mową nieoryginalną (choć oryginalnie ją przetwarza) i czerpie z konkretnych realiów swego czasu, a tym samym określa swoją wartość przez krytyczne do nich (do języka zwłaszcza) odniesienie.

Socrealizm, choć gwałtownie odrzucony, wpłynął na dalszy bieg historii literatury; bezpośrednio na twórczość początkowego okresu jej odradzania, pośrednio i tylko w pewnym sensie - na dalsze dzieje literatury polskiej, która kształtowała swoją specyfikę przez nieufność do różnych form oficjalnej mowy (nie tylko do twórczości socrealistycznej). Literatura, zrazu wyzwolona z restrykcyjnych ograniczeń artystycznych, musiała zmierzyć się z innymi formami językowej opresji; z ograniczeniem wolności słowa i machiną cenzury czy z powszechną biurokratyzacją życia (mnożeniem wniosków, protokołów, pism, zażaleń, skarg itd.). Upowszechnione formy komunikacji urzędowej przenikały do polszczyzny ogólnej, usztywniały język. Zniewolony i wielorako uwikłany w publiczne sprawy, wymagał rozbrojenia, obnażenia, krytyki, analizy, toteż literatura drugiej połowy XX wieku, wedle słów Janusza Sławińskiego, utrzymywała mowę „w stanie podejrzenia” (2001: 300). Jak pisał Michał Głowiński, „w większości przypadków dzieła literackie [tego okresu - MB] są krytyką języka nie z powodu takiego czy innego metajęzykowego epizodu, ale jakby - całym sobą, całą swą strukturą, całym swym językowym uposażeniem" (1997: 257). 
Autorzy poodwilżowych tekstów stanęli przed podwójnym zadaniem: rozbroić mowę cudzą i wypracować mowę własną. Było to zadanie orientujące twórczość wielu poodwilżowych pokoleń, środowisk, grup literackich; jedne koncentrowały swoje starania bardziej na krytyce nowych publicznych form wypowiedzi i ochronie mowy prywatnej, drugie zmierzały w większym stopniu do uformowania własnej artystycznej specyfiki - przez odrzucenie koturnowego tonu powieści produkcyjnych i schematyzacji wypowiedzi. Najdalej od zanegowanej przez nich mowy był język, którego sami używali w codziennej komunikacji: jednostkowy, potoczny, bliski zwyczajnemu doświadczeniu. Zabiegi banalizowania i wulgaryzowania wypowiedzi jeszcze bardziej oddalały język od hieratycznej mowy socrealizmu. Z czasem w literaturze wypracowała się konwencja podejrzliwej, ironicznej analizy języka, która oderwała się od swego źródłowego historycznego kontekstu, od negacji oficjalnych form publicznej mowy i uczyniła swoim przedmiotem język już zupełnie inaczej uwikłany w schematy i formy wysłowienia.

Podstawową właściwością literatury modernistycznej jest operowanie „mową własną”, która w różnych okresach tej wielorodnej formacji i w twórczości każdego autora znaczyła oczywiście co innego. W pierwszej połowie XX wieku język literacki przeciwstawiał się potocznej mowie, w drugiej połowie wieku - określał swój charakter przez odniesienie do tego rejestru języka, przez jego przyswojenie i przetworzenie. Z czasem, od lat 70., literackie eksperymenty czyniły z wyjściowo potocznego języka mowę coraz bardziej oryginalną $\mathrm{i}$ artystycznie wyrazistą; cudze wypowiedzi, ułożone w kontrasty, zdeformowane, zdemontowane - bardziej zwracają uwagę na swój tworzywowy charakter, na eksperymenty, których są przedmiotem: readymade’ową rekontekstualizację, groteskę lingwistyczną, recykling słów, awangardowe kompozycje dźwiękowe...

W historii literatury polskiej wraca modernistyczna dominanta „widoczności języka”, choć język literatury składa się z odłamków cudzej mowy; nie odcina się od potoczności, jak w literaturze wczesnego modernizmu i — w mniejszym stopniu - w dwudziestoleciu międzywojennym, którego twórczość w pewnej mierze utorowała tendencję do poodwilżowego przyswajania nieliterackich odmian literatury (by wspomnieć o twórczości futurystów, poezji Tuwima z okresu skamandryckiego czy niektórych utworach Peipera, np. Kronice dnia z tomu $R a z$, wierszach Przybosia, np. z tomu $Z$ ponad, ale też o twórczości Witkacego i Gombrowicza).

Jak wskazywał Sławiński, okres pierwszej dekady po „odwilży” „zawdzięczał swoją dynamikę ewolucyjną przede wszystkim dwóm czynnikom. Pierwszy to energia nieprawomyślności — ruch zdecydowanego oddalania się od literatury doby stalinowskiej; drugi — rewolucja retrospektywna: odrabianie zaległości i swobodne zagnieżdżanie się mowy poetyckiej we własnej historii” (2001: 318). Zdaniem uczonego „odwilż” skierowała uwagę ówczesnych pisarzy na przerwane tendencje rozwoju literatury w dwudziestoleciu międzywojennym:

Ruch porzucania socjalistycznej przeszłości był [...] zarazem ruchem ku literackim przeszłościom wyklętym w latach stalinowskich, ku doświadczeniom pisarskim wtedy przekreślonym, zagłuszonym, uznanym za niebyłe lub wrogie; był ruchem nawiązywania do poetyk, stylów i epok, z którymi więzi zostały brutalnie potargane. Przywrócić czasowi teraźniejszemu przeszłość utraconą — to wydawało się tak poetom, jak krytykom poezji zadaniem naczelnym. (Sławiński 2001: 318) ${ }^{4}$

4 W podobnym tonie wypowiada się Agata Stankowska. Badaczka w swojej książce poświęconej ówczesnym sporom o wyobraźnię poetycką traktuje socrealizm jako zdarzenie traumatyzujące, wyznaczające punkt zwrotny w historii literatury polskiej i kierunek dalszych jej przemian (Stankowska 2013). 
Istotnie wiele przerwanych wojną i socrealizmem tendencji odrodziło się po 1956 roku, na przykład modernistyczne zainteresowanie językiem, skutkujące potrzebą jego analizy. Jednak radykalna krytyka praktyk językowych, związana ze zjawiskiem intensywnego napływu form nieliterackich do języka literatury, i wypracowanie technik przetwarzania polszczyzny nieliterackiej to oryginalne zdobycze literatury drugiej połowy $\mathrm{XX}$ wieku ${ }^{5}$. Z czasem palący w latach 50., 60., 70. XX wieku problem prawdy i zmyślenia, autentyczności i fałszu języka nabiera innych znaczeń, przestaje być nadrzędnym zagadnieniem literatury, a eksperymenty, służące w równej mierze krytyce publicznej mowy i komplikowaniu znaczeń artystycznych, autonomizują swoje znaczenie. Choć narastająca w literaturze polskiej od połowy lat 50. tendencja do asymilowania i przetwarzania form nieliterackich przybierała w ostatnim sześćdziesięcioleciu różne postacie i miała nieco inne funkcje w różnych momentach tego okresu, to trzeba przyznać, że „widoczność języka” — dodajmy: nieliterackiego — jest wyrazistą cechą innowacyjnej, eksperymentalnej twórczości rozmaitych autorów — zarówno pojedynczych, osobnych, niepowiązanych wspólnym programem czy doświadczeniem pokoleniowym, jak i grup czy formacji literackich. Pozwala to sądzić, że inwazja twórczo przekształcanych form nieliterackich to jeden z istotniejszych wyznaczników modernizmu drugiej połowy XX i początków XXI wieku.

\section{Bibliografia}

Bachtin Michaił (1970), Stowo w powieści [w:] Rosyjska szkota stylistyki, red. Mayenowa M.R., Saloni Z., Warszawa.

- (1986), Problem gatunków mowy [w:] tegoż, Estetyka twórczości stownej, przeł. D. Ulicka, oprac. i wstęp E. Czaplejewicz, PIW, Warszawa.

Białoszewski Miron (2017), Polot nad niskimi sferami, oprac. M. Byliniak, M. Sokołowska, PIW, Warszawa.

Bolecki Włodzimierz (2012), Modalności modernizmu. Studia, analizy, interpretacje, Wydawnictwo IBL, Warszawa.

Buczkowski Leopold (1970), Uroda na czasie, PIW, Warszawa.

5 Na marginesie wypada przy tym zauważyć, że zjawisko wypierania języka literackiego było również elementem manifestów futurystycznych, które postulowały odwrót od tradycji pięknego opowiadania, prostotę i dosadność języka oraz demokratyzację literatury. Jak wiadomo, nie miały one jednak takiej trwałości jak omawiane przeze mnie tendencje, które zresztą wiążą się z innego rodzaju przetwarzaniem mowy niż te znane z wierszy futurystów. Zob. Gazda 1974. 
Bukowiecka Marta (2015), Antyliterackie, a więc literackie. O Nifikormach Edwarda Redlińskiego, „Teksty Drugie”, nr 4.

- (2019), Preparowanie mowy. Uroda na czasie Leopolda Buczkowskiego, „Teksty Drugie”, nr 3. Gazda Grzegorz (1974), Futuryzm w Polsce, Wrocław.

Głowiński Michał (1997), Czy literatura może być wzorem mowy? [w:] tegoż, Narracje literackie i nieliterackie, Universitas, Kraków.

Karpowicz Agnieszka (2012), Proza życia. Mowa, pismo, literatura (Biatoszewski, Stachura, Nowakowski, Anderman, Redliński, Schubert), Wydawnictwa UW, Warszawa.

Kirchner Hanna (1996), Leopold Buczkowski, albo uroda na czasie [w:] Sporne postaci polskiej literatury wspótczesne. Kontynuacje, red. Brodzka-Wald A., Burska L., Wydawnictwo IBL, Warszawa.

Kluba Agnieszka (2014), Autoteliczność, referencyjnossć, niewyrażalność. O nowoczesnej poezji polskiej (1918-1939), Wydawnictwo Naukowe UMK, Toruń.

Nycz Ryszard (1978), Teufelsdröckh redivivus albo o pewnym dialogu tekstowym, „Teksty”, nr 1.

- (2000), Tekstowy świat; poststrukturalizm a wiedza o literaturze, Universitas, Kraków.

- (2012), Poetyka doświadczenia. Teoria - nowoczesność - literatura, Wydawnictwo IBL, Warszawa.

- (2013), Jezyk modernizmu. Prolegomena historycznoliterackie, Wydawnictwo Naukowe UMK, Toruń.

Orska Joanna (2004), Przetom awangardowy w dwudziestowiecznym modernizmie, Universitas, Kraków.

Owczarek Bogdan (2014), O kilku ideach ważnych dla rozumienia prozy Leopolda Buczkowskiego, „Pamiętnik Literacki”, nr 3.

Redliński Edward (1982), Nikiformy, Czytelnik, Warszawa.

Różewicz Tadeusz (2006), Poezja, t. 2, Wydawnictwo Dolnośląskie, Wrocław.

- (2008), Kup kota w worku. (work in progress), Biuro Literackie, Wrocław.

Sławiński Janusz (2001), Próba porządkowania doświadczeń [w:] tegoż, Przypadki poezji, Universitas, Kraków.

Stankowska Agata (2013), „Wizja przeciw równaniu”. Wokót popaździernikowego sporu o wyobraźnię twórcza, Wydawnictwo Poznańskiego Towarzystwa Przyjaciół Nauk, Poznań. 